\title{
Spiritual Alternative to the Floundering Biological Perspective for Mental Disorders and Life: A Life-After-Life Perspective
}

\author{
Ted Christopher* \\ Rochester Center for Biomedical Ultrasound, University of Rochester, NY, USA
}

"Corresponding author: Christopher T, Rochester Center for Biomedical Ultrasound, University of Rochester, 71 Azalea Road, Rochester, NY, 14620, USA, Tel: +1 585-275-2121, E-mail: tchrist7@rochester.rr.com

Received: December 20, 2019; Accepted: January 06, 2020; Published: January 13, 2020

\begin{abstract}
I briefly argue here that the biological perspective is failing and then go on to sketch out an alternative spiritual or soul-based perspective. The failure of the biological or brain-only perspective on mental disorders is consistent with the encompassing failure of the scientific model of life. There are easy to find unusual behaviors which rebut the modern materialist paradigm. A general problem, though, has unfolded in the failure of the DNA/genetic model of inheritance. Some possible objective support for the pre modern, reincarnation-based understanding of life is considered. The subsequent and main topic herein, though, is the possible psychological import of that vision. Our difficulties including our mental suffering could be significantly a function of our ignorance about deeper matters. The pre modern reincarnation vision appears to offer both objective insights and also a more constructive perspective.
\end{abstract}

\section{Introduction - Alternative Background}

Previous work by the author has introduced the somewhat novel notion that science's molecular-only vision of life is easily rebutted via some accepted, albeit exceptional behaviors [1,2]. The larger point made in those works is that the general problem facing the scientific model is with regards to the general expectations placed on DNA as a vehicle for inheritance. For over a decade I have pointed this out and that message has stayed aligned with the unfolding missing heritability problem. It should be increasingly clear to people doing (personal) genetic-related research that the venerated DNA model is in serious trouble. The era of immense faith in DNA as the language of life, and also as a vehicle for enormous hype and confidence, should be drawing to a close.

The associated heritability mystery can be approached in alternative fashion. Rupert Sheldrake has argued that the expectations for the functioning of DNA should have been seen as excessive all along. He does so by simply noting the enormous complexity challenges starting with the requisite specifications for the shape of proteins and further along the structuring of cells $[3,4]$. His approach picks up on the historical work which suggested the need for morphogenic (or

Citation: Christopher T. Spiritual Alternative to the Floundering Biological Perspective for Mental Disorders and Life: A Life-After-Life Perspective. J Anxiety Depress. 2020;3(1):118. 
www.yumedtext.com | January-2020 | ISSN: 2582-3264

guiding) fields in order to help specify organisms' very complicated functional forms and also behavioral tendencies. With regards to protein folding challenge Sheldrake wrote:

- Genes code for the linear sequences of amino acids in proteins, which then fold up into complex three-dimensional forms. Wolpert's wager presupposes that the folding of proteins can be computed from first principles, given the sequence of amino acids specified by the genes. So far, this has proven impossible. As in all bottom-up calculations, there is a combinatorial explosion. For example, by random folding, the amino acid chain of the enzyme ribonuclease, a small protein, could adopt more than $10^{40}$ different shapes, which could take billions of years to explore. In fact, it folds into its habitual form in $2 \mathrm{~min}$.

The underlying explanatory idea is of physical fields utilizing memory so as to guide organisms - and within them, proteins in physical ways. Sheldrake has an existing bet with the biologist Lewis Wolpert with regards to the ability of scientists to genomic-ally predict the developmental outcome for a 959 cell worm, Caenorhabditis elegans by the year 2029 [5].

Sheldrake has done a number of interesting and novel investigations but I note here a few shortcomings with regards to his morphogenetic suggestions. First, he uses the similarity found between monozygotic twins, in particular those raised separately, as critical evidence for the functioning of morphogenetic fields. He suggests that such fields are making separated twins more similar via their mutual morphogenetic field interaction (in sort of a resonance fashion). The problem here is that the main mystery expressed by monozygotic twins - irregardless of how they were raised - is their inexplicable differences. That has always been a very big and quite frankly under-appreciated mystery. Morphogenetic possible contributions to behavioral alignment do not appear to be helpful in the case of differentiating monozygotic twins. How could such fields possibly help explain such mysteries as having the concurrence rate of male exclusive homosexuality be only about 20 to 30 percent among such (male) twins [6]?

Another shortcoming with a physical field-based explanation for our inheritance is one of significance. It really doesn't appear to change the basic deterministic paradigm of scientific materialism. It would seem to just see to add some more physics to the phenomena of life. A final shortcoming considered here is in relation to our challenges including mental difficulties. Can morphogenic fields offer any insight into our suffering? Do they offer any potential help with that suffering?

I move on to consider the premodern life-after-life explanation for the missing heritability. Following through with the previous discussion, a life-after-life explanation would place the memory-based contribution on the incarnating souls. This approach would provide some traction for explanations of the enormous variance present in the personalities of many animals [7,8]. It would also provide obvious explanations for such very puzzling phenomena as prodigies and transgender children. In general, an underlying dynamic of souls' being drawn to their parents-to-be, along with their tendency to maintain behavioral inclinations, allows for a gross fit to the missing heritability problem. In a simple example, a number of problematic behaviors like excessive drinking of alcohol and also smoking appears to involve genetic contributions [9]. Instead of expecting a (questionable) DNA/physical basis for that problematic habit, the transcendental alternative is to view the habit as an expression of behavioral continuity. A soul previously got stuck on an unhealthy habit and that rut continues in their subsequent human life. Another possible simple explanation is with regards to (otherwise) inexplicable phobias. 
www.yumedtext.com | January-2020 | ISSN: 2582-3264

My earlier work outlines and in some cases details some particular explanations based on reincarnation. That work includes discussions on specific hypothesis for some mental illnesses [10,11]. I will be brief here, though, to avoid undue redundancy. The backdrop to my contributions are of course the earlier work of official researchers like Ian Stevenson, and then much more generally, the prevalence of this perspective in the premodern world. Many aspects of life do not require an advanced modern degree for their appreciation. To my knowledge my particular contribution is in pointing out the potential general import of reincarnation to a number of non-taboo behavioral phenomena and also the big missing heritability problem (these may well have been apparent long ago to some uneducated people too). A heritability connection would suggest that reincarnation's life-after-life dynamic could be fundamental to life and evolution. Such a bottom-up, soul-based contribution would then not only contribute to some particular behavioral conundrums, it could also be involved with broader dynamics.

In this short paper I will outline the deeper possible perspectives offered by a reincarnation model for our difficulties, and also the large potential upside to the associated dualistic state. One way and another, we are all challenged by mental stress and suffering. A deeper perspective on that ongoing reality could be helpful in both a short term (this life) well-being sense and also for the long haul.

\section{Some Evidence for a Soul and its Significance}

I get started with some basic information about our innate religious or spiritual perspective. It turns out that from interviews with young children it has become apparent that kids are somehow born with a faith in a spiritual aspect of life. In the 2012 book, Born Believers - The Science of Children's Religious Belief, Justin L. Barrett presents some of the growing evidence that infants tend to possess an innate sense of the existence of souls/God/gods, to be believers in what Barrett called a "natural religion" [12]. Born Believers contains some surprising examples including ones in which atheists 'positions were rebutted by their young children. As Barrett wrote "children are prone to believe in supernatural beings such as spirits, ghosts, angels, devils, and gods during the first four years of life" [13]. He later added:

Exactly why believing in souls or spirits that survive death is so natural for children (and adults) is an area of active research and debate. A consensus has emerged that children are born believers in some kind of afterlife, but not why this is so [14].

Staying true to the prevailing dogma, though, Barrett had these striking findings simply pushed back into materialism. Even as a practicing Christian, Barrett concluded that these are simply delusional tendencies derived from evolution and nurture "biology plus ordinary environment".

How such spiritual/religious beliefs could have arisen out of our evolutionary journey and ultimately been stored in DNA, is not easy to see though. At the beginning of his book Barrett did offer a form of religious explanation that had been provided by an Indian man he met on a train. In Barrett's words that man had explained:

- That on death, we go to be with God and are later reincarnated. As children had been with God more recently, they could understand God better than adults can. They had not yet forgotten or grown confused and distracted by the world. In a real sense, he explained, children came into this world knowing God more purely and accurately than adults do [15]. 
www.yumedtext.com | January-2020 | ISSN: 2582-3264

The fact that we are born with a spiritual perspective should be more commonly known and wondered about. Of note here, is that the reincarnation vision suggests that we have been around the life-death block and that will continue with that dynamic. Also of note, here is the possibility that the underlying disembodied-to-embodied dynamic is fundamental to our psyche challenges. Our potent unconscious tendencies and conflicts could reflect this difficult transition as well as our previous embodied history.

Next, I move on to consider an example relevant to the possible existence of a soul as well as our late life difficulties. That example involves the phenomenon of terminal lucidity which was discussed in a Scientific American blog piece by the psychologist Jesse Bering entitled, “One Last Goodbye/ The Strange Case of Terminal Lucidity” [16]. In his write up Bering considered something that was possibly first officially characterized by a German biologist Michael Nahm in a 2009 article. Nahm described terminal lucidity as:

- The (re-)emergence of normal or unusually enhanced mental abilities in dull, unconscious, or mentally ill patients shortly before death, including considerable elevation of mood and spiritual affectation, or the ability to speak in a previously unusual spiritualized and elated manner.

In a subsequent Nahm article, written along with Bruce Greyson, it was mentioned that in a study of 49 cases, 41 of the cases involved surprising verbalizations occurring during the last week of life. Furthermore, in 21 of the cases the verbalizations came on the same day as death. In some cases, severely mentally limited individuals have gradually returned to near normal lucidity before their deaths. One case involved a man who had been completely catatonic for nearly 2 decades before his reemergence to a near normal state.

Other cases involved sudden lucidity. In one case Bering reported that a 92-year-old woman "with advanced Alzheimer's disease, hadn't recognized her family for years, but the day before her death, she had a pleasant bright conversation with them, recalling everyone's name and was even aware of her age and where she'd been living all this time". But the most striking case involved a severely disabled young woman named Anna ("Kathe") Katherina Ehmer and it occurred in 1922. Her case had substantial verification in that as a patient in a mental hospital her sudden lucidity episode was observed by that hospital's chief physician Wilhem Wittneben and also its director Friedrich Happich. The two men independently and apparently consistently (supposedly “over the years”) communicated Kathe's remarkable spontaneous event. Kathe had been severely disabled and Happich described her as having been from birth on:

- $\quad$ seriously retarded. She had never learned to speak a single word. She stared for hours on a particular spot, then fidgeted for hours without a break. She gorged her food, fouled herself day and night, uttered an animal-like sound, and slept ... never taking notice of her environment even for a second.

She also apparently had suffered a number of bouts of severe meningitis infections which were believed to have damaged her cortical brain tissue. She also experienced a bout of tuberculosis which led to the amputation of a leg. Shortly after the removal of her leg Kathe was lying in bed and was approaching death. At this point a number of staff members, including Wittneben and Happich, gathered to observe her stunning rejuvenation. As Happich described it: 
www.yumedtext.com | January-2020 | ISSN: 2582-3264

- Kathe who had never spoken a single word, being entirely mentally disabled from birth on, sang dying songs to herself. Specifically, she sang over and over again, "Where does the soul find its home, its peace? Peace, peace, heavenly peace!" For half an hour she sang. Her face, up to then so stultified, was transfigured and spiritualized. Then she quietly passed away.

This amazing report is both an obvious challenge to materialism as well as suggestive of the presence of a soul. To his credit Jesse Bering - with a job in psychology and at one point a blog at Scientific American - can write in super-understated fashion that, "on face value, one has to admit that the story of Kathe Ehmer is something of a puzzle". Additionally, Bering had some personal connection to this matter since he had been with his dying mother who had managed "five minutes of perfect communion with me when, ostensibly, all her cognitive functions were already lost". I suggest here that paired up with the implications of our innate religion, terminal lucidity suggests that there could be a soul which appears to be largely independent of the physiological state and also tends to cycle through lives.

I wind down here on this introductory look at evidence for a soul and its possible implications by moving on to a description of a profound transcendent experience. This offers a very positive look at the potential of our dualistic state. Here I provide an example of an enlightenment (or Self-realization) account as given in a modern introduction to Zen practice, The Three Pillars of Zen [17]. The following excerpts are described as having been written by a Japanese executive in the 1950's. In a note to his Zen teacher the executive had written:

- You remember the discussion which arose about Self-realization centering around that American. At that time I hardly imagined that in a few days I would be reporting to you my own experience.

The executive went on to describe that during the train ride home from the monastery with his wife he had been deeply struck whilst reading a passage from Zen literature. The particular passage read was "I came to realize clearly that Mind is no other than mountains and rivers and the great wide earth, the sun and the moon and the stars".

This passage somehow deeply resonated with this man and his meditational experiences. During the subsequent days it triggered an enlightenment experience (in the awkward company of his family and brother and sister-in-law). During his first night home he wrote that:

- At midnight I abruptly awakened. At first my mind was foggy, then suddenly that quotation flashed into my consciousness: "I came to realize that Mind is no other than mountains, rivers, and the great wide earth, the sun and the moon and the stars". And I repeated it. Then all at once I was struck as though by lightening, and the next instant heaven and earth crumbled and disappeared. Instantly, like surging waves, a tremendous delight welled up in me, a veritable hurricane of delight, as I laughed wildly and loudly: “Ha, ha, ha, ha, ha, ha! There's no reasoning here, no reasoning at all! Ha, ha, ha!" The empty sky split in two, then opened its mouth and began to laugh uproariously: "Ha, ha, ha!".

The executive then went on to exclaim, "I've come to enlightenment! Shakyamuni [i.e., the Buddha] and the patriarchs have not deceived me!" This revelatory experience then got a bit awkward as his family was clueless about his inner experiences so the executive downshifted and apologized for his outbursts. 
www.yumedtext.com | January-2020 | ISSN: 2582-3264

The next day the executive went to visit a Zen teacher and he was simply overcome with joy and wept. That teacher reportedly commented, "it is rare indeed to experience to such a wonderful degree. It is termed 'Attainment of the emptiness of Mind'. You are to be congratulated." As a potentially crude explanation here, somehow his extensive meditation practice plus the triggering of the quote allowed him to vividly break through the deeply-entrenched, me-and-the-world story that we operate within. I go further here to suggest that such a breakthrough could reflect a recognition by the underlying soul of its own existence. Thus the tangled and suffering-prone defaults in our existences - entailing the ceaseless cycles of fear and desire - can be psychically dropped.

The executive's enlightenment breakthrough continued across the next few days and left him "laughing and weeping" extensively. The executive then contacted his original teacher in hopes of offering some inspiration to his monks and also in hopes of helping the novice American. To the latter he suggested letting him know that "even I, who am unworthy and lacking in spirit, can grasp such a wonderful experience when time matures". He further suggested telling that American who not surprisingly was hoping for enlightenment within a week - that, “don’t say days, weeks, or even lifetimes. Don’t say millions of billions of kalpa. Tell him to vow to attain enlightenment though it takes the infinite, the boundless, the incalculable future". A kalpa is an extremely long period of time.

The executive's subsequent diary entries included, "Am totally at peace at peace at peace", "Am supremely free free free free free free", and "The substance of Mind - this is now luminously clear to me". And finally in a concluding paragraph he wrote that:

- The ancients said the enlightened mind is comparable to a fish swimming. That's exactly how it is - there's no stagnation. I feel no hindrance. Everything flows smoothly, freely. Everything goes naturally. This limitless freedom is beyond all expression. What a wonderful world.

The executive finally stated simply, "I am grateful, so grateful."

Of some note here is that an enlightenment experience like the above is simply not on the radar screen of science. Along those lines, years ago in talking with a highly educated physicist they simply categorized such revelations as episodes of schizophrenia or craziness. They certainly don't make equation-sense. To Sam Harris' credit, though, his Waking Up is trying to legitimatize such experiences which have a long history of occurrences in meditational/mystical/religious traditions.

I will return to criticize Harris' book and the associated contemporary meditation scene later.

I have been involved with Buddhist daily practices for over 40 years. During that time, I have been around some very committed practitioners, including of course some monastic figures, and based on that my sense is that such transformations really are profound and can having lasting impacts. In very simple physical terms it is as though the default condition as human beings were to walk around with pebbles in our shoes. Enlightenment in that simple analogy is when a person finds a way to shed those pebbles. Thus, you can sense in others that via a significant enlightenment experience they are considerably more at ease with themselves and life. Another physical analogy would be that they learn to ride a bicycle, not 
www.yumedtext.com | January-2020 | ISSN: 2582-3264

an ordinary bicycle, but the bike of life. It is a big deal and that transformation can indirectly motivate others to try to meditate.

I add two references here of potential additional interest to readers. The first is of an even deeper enlightenment experience that also happened in Japan. That experience happened to a very sick young Japanese woman, Yaeko Iwasaki, in the 1930's and is also described in Kapleau's The Three Pillars of Zen (Chapter 6 and is also available online at [18]). The inherent sense of responsibility, humility, and deeper perspective on life and death suggested through this experience are noteworthy. Additionally, after marching through a sequence of breakthroughs in only a week Iwasaki came to realize the significance of deep enlightenment experiences and accept her pending death (which she could sense coming). Finally, the fact that this happened to a lay person is quite remarkable.

A second reference that might be of interest for additional reading is the story of a Japanese man, Ittetsu Nemoto, who plunged into traditional (and barely still existing) monastic Rinzai Zen training and then subsequently dedicated himself to helping out with suicide prevention efforts in Japan. A fine article, The Last Call, describing this was published in the New Yorker magazine and was written by Larissa MacFarquhar [19]. Nemoto's journey is remarkable for a number of reasons. He managed in his intense journey to stay clear of two meditational tendencies - the first is too much withdrawal (admittedly this option has faded a lot) and secondly his apparent complete lack of interest in intellectualizing (Nemoto is no Sam Harris). But MacFarquhar's article nicely portraits Nemoto's extremely rigorous training (forget the common Western, do-nothingand-pretend-your-enlightened routine); seemingly miraculous Self-realization experience (apparently an initial or Kensho experience); serious dedication to helping in the outside world; and his sober conclusion that we learn and are potentially transformed through suffering - and likely intense suffering at that. That last point seems to be unpopular in general and probably less so amongst intellectuals. There really could be a significant upside to our struggles.

An additional related point. Years ago when I attended meetings for an anti- (or really reduced)-nuclear weapons group there was another attendee that drew my attention. That attendee was an older man who seemed amazingly at ease with life and himself. Eventually I spoke to the man after one of the meetings and asked him about his background. With my own background (and biases) I assumed he must have been involved with meditation (and probably for years at that). But that was not the case. The man reported that he had been involved with a small Christian church. Perhaps similarly, the book And There Was Light by Jacque Lusseyran reports on the jaw-dropping achievements of a group of young people in the French resistance [20]. Lusseyran, and apparently some of his other very brave and deeply insightful colleagues, seemed to have been Christians via their own understanding. Whatever the vehicle, though, such spiritual transformations do appear to be rare (a point often neglected in the modern literature [21]). A general positive point, though, is that based on my personal observations I think some people can find real benefit (and with it, be quite beneficial) as a result of their religious trajectories (even if they don't achieve a deep transformation).

\section{A Spiritual Perspective}

The previous coverage suggested that the material-only DNA-directed perspective is floundering and moreover that a lifeafter-life perspective offers an alternative with substantial explanatory strengths. That coverage also suggested some evidence for the requisite existence of a soul. Finally, it provided some additional evidence for the possibility of a big release from our 
www.yumedtext.com | January-2020 | ISSN: 2582-3264

suffering, in what is sometimes referred to as a self-liberation experience. Of some note here is that a capitalized "self" or "Self" is often used to denote the resulting liberated self (or potentially soul). Thus the goal of spiritual training might be described as experiencing Self-realization via a liberation from the self.

This section discusses the potential psychological import of this deeper perspective. One relevant and remarkable book is $I$ AM THAT by Sri Nisargadatta Maharaj (a somewhat analogous spiritually insightful work is the small book, Zen Mind, Beginner's Mind, by Shunryo Suzuki). Nisargadatta seems to have plumbed the depth of meditation and via that route gotten an intimate view of our inner psyches and difficulties. Tradition has it that if you stay with a mediation practice for a long time - one way and another - you are going to get a front row seat on your inner dramas and dynamics (which otherwise tend to make themselves known indirectly thru our outer compulsions and conflicts). Nisargadatta somehow was very lucid at providing insightful suggestions on this inner landscape, as well as the deeper freedom available thru enlightenment experiences.

Below is an extended excerpt from a discussion that took place at his meditation abode (which was located upstairs from his modest small store). Of note here is that the references to "pain" might be significantly motivated by the discomfort sitters often face in extended mediation efforts. Sitting may look boring, but one way and another, it isn't. Continuing, "Q" designated the questioner and " $\mathrm{M}$ " designates Nisargadatta (the Maharaj). Here goes:

Q: Do you advise shunning pleasure and pursuing pain?

M: No, nor pursuing pleasure and shunning pain. Accept both as they come, enjoy both while they last, let them go, as they must.

Q: How can I possibly enjoy pain? Physical pain calls for action.

M: Of course. And so does mental. The bliss is in the awareness of it, in not shrinking, or in any way turning away from it. All happiness comes from awareness. The more we are conscious, the deeper the joy. Acceptance of pain, non-resistance, courage and endurance - these open deep and perennial sources of real happiness, true bliss.

Q: Why should pain be more effective than pleasure?

M: Pleasure is readily accepted, while all the powers of the self reject pain. As acceptance of pain is the denial of the self, and self stands in the way of true happiness, the wholehearted acceptance of pain releases the springs of happiness.

Q: Does the acceptance of suffering act the same way?

M: The fact of pain is easily brought within the focus of awareness. With suffering it is not that simple. To focus [on] suffering is not enough, for mental life, as we know it, is one continuous stream of suffering. To reach the deeper layers of suffering you must go to its roots and uncover their vast underground network, where fear and desire are closely interwoven and the currents of life's energy oppose, obstruct and destroy each other.

Q: How can I set right a tangle which is entirely below the level of my consciousness?

M: My being with yourself, the 'I am'; by watching yourself in your daily life with alert interest, with the intention to understand rather than judge, in full acceptance of whatever may emerge, because it is there, you encourage the deep to come to the surface and enrich your life and consciousness with its captive energies. This is the great work of awareness; it removes obstacles and releases energies by understanding the nature of life and mind. Intelligence is the door to freedom and alert attention is the mother of intelligence [22]. 
www.yumedtext.com | January-2020 | ISSN: 2582-3264

This passage captures a good chunk of the general spirit of meditation and with it I suggest healthy living. You sit and try to stay present (a focal practice can help with that), and then stay there come what may. In a simple everyday way, I think as adults we all know this routine. Sometimes deeply committed efforts (the stuff we can not turn back from), as for example being a parent in a difficult situation, can paradoxically be excruciating, liberating, and of course focusing. The relevant advice in such circumstances is commonly to "Hang in there".

Continuing with this parallel, in Andrew Solomon's Far From the Tree Solomon reports on some of the amazing commitments he observed among parents of children with disability. One episode deals with a woman who had been seriously tested by her Down syndrome child. In asking about her observations from her work with other parents in similar circumstances, and in particular did they share her energetic engagement, she commented, "they all do. That's the wild thing about special needs parents. This comes raging out of you. I feel such strength and courage in these women" [23]. Likewise, people seriously committed to meditation, or more generally engaged living, could be in a relatively good position when life inevitably provides the serious challenges (including of course pain and suffering). One of the miracles that meditation - or other form of spiritual practice - can help with, is that painful situations can somehow transform themselves and you can come to appreciate a little of Nisargadatta's final characterization above.

The traditional framing of such practices is sometimes in a life-after-life perspective. Within that perspective, one practices so that one can further appreciate life's lessons, facilitate helping others, and grow some - in what might be described as a spiritual sense. Traditionally people aligned with such practices didn't expect some final enlightenment breakthrough (at least in this life). That traditional modesty in such matters could simply have been realism. On that note I suggest that very few contemporary meditation teachers - certainly in the West - have more than a superficial feel for Nisargadatta's perspective and teachings.

I add here a little more from the spiritual training front. I recently had a chance to see two talks by a Spanish man who had spent a number of years on the spiritual training circuit. His particular approach was via Tibetan Buddhism and he had apparently secured close relationships with some highly trained Tibetans as well as a few Western associates. His first talk was on the nature of the teaching he had received. His second talk was independent of those teachings and simply laid some advice based on his personal retreat experiences. An interesting side note here was that despite his significant Spanish accent he had little trouble communicating his points. It seems that really important matters in life can communicate themselves in simple ways.

The deeper point conveyed in his talks, though, was that this guy had uncovered and nicely communicated some serious wisdom with regards to life. I was rather struck and impressed with his commitment to helpful communication which several times included a polite, but determined, effort to challenge some of his audiences' views. He said something that was very helpful to me in one brief exchange. We all are susceptible to psychological ruts and sometimes a simple insightful prod can really help.

In his own way this man provided some substantial optimism with regards to dealing with lives challenges. His own spiritual commitment is likely more than most of us can manage, as part of his practices he had spent over 12 years on personal 
www.yumedtext.com | January-2020 | ISSN: 2582-3264

retreats! And yet he communicated and seemed to embody a basic message that we can all hang-in-there and get something deeper out of our lives. I was also impressed with his honesty about his own status. He said that he was not enlightened nor really qualified to officially teach but he was content to continue with his spiritual journey. From my experiences with Buddhism or Buddhist-derived teachers in the West this was a wonderful thing to hear. None of the prevalent hype or exaggeration (as for example communicated in Waking Up), just good old honesty. His presentation and admission was realistic given the longstanding sober historical record of meditational efforts, he had not experienced or obtained deep enlightenment but was simply moving in that direction. Within a life-after-life perspective it makes sense to just keeping learning, hanging-in-there, and helping out and eventually deeper developments will happen on their own.

A sober aspect of the talks, though, was the limited turnout. In his friendly (and accented) way this guy was giving really serious and helpful talks. The talks were also given at a library and thus were free. I was extremely appreciative. On the other hand, his message didn't contain attractive messages including easy enlightenments (or fast solutions to life's difficulties) and it wasn't framed in an intellectually pleasing fashion (likely contains references to glorious science in the fashion of Westernized Buddhism). I think in all maybe a dozen people attended the two talks in total.

\section{Conclusion}

Life inevitably entails challenges including plenty of mental ones. Within the premodern life-after-life perspective this is to be expected and can be viewed as providing positive learning experiences. That traditional perspective provides a very different outlook on life beginning with the assertion that we can't die and also have possible routes to improving future experiences for ourselves and others. This provides for a substantial motivational boost for dealing with our unfolding environmental and sustainability crises. This alternative perspective may also provide traction for traditional religious perspectives, perspectives which somehow appear to show up in our innate understandings. Perhaps there is some overlap between such understandings and the relative success of traditional societies in dealing with a mental illness like schizophrenia [24].

\section{REFERENCES}

1. Christopher T. Science's Big Problem, Reincarnation's Big Potential, and Buddhists' Profound Embarrassment. Religions. 2017;8(8):155.

2. Christopher T. A Hole in Science: An Opening for an Alternative Understanding of Life. Expanded 3rd ed. Baltimore: Wise Media Group, USA; 2017.

3. Sheldrake R. The Presence of the Past. Rochester, VT: Park Street Press, USA; 2012.

4. Sheldrake R. Science Set Free: 10 Paths to New Discovery. New York, NY: Deepak Chopra Books, USA; 2012.

5. Sheldrake $\mathrm{R}$ and Wolpert L. (Sheldrake bet) The Genome Wager. Available from: https://www.sheldrake.org/reactions/the-genome-wager [Accessed on November 9, 2019].

6. Collins F. The Language of Life: DNA and the Revolution in Personalized Medicine. New York, NY: HarperCollins, USA; 2010. 204-5 p. 
www.yumedtext.com | January-2020 | ISSN: 2582-3264

7. Angier N. Even Among Animals: Leaders, Followers and Schmoozers. New York Times, April 5, 2010. Available from: www.nytimes.com.2010/04/06/science/06angi.html [accessed on 7 July 2017].

8. Christopher T. A Hole in Science: An Opening for an Alternative Understanding of Life. Expanded 3rd ed. Baltimore: Wise Media Group, USA; 2017. See Chapter 3.

9. Nurenburger JI and Bierut LJ. Seeking the Connections: Alcoholism and Our Genes, Scientific American, April 2007.

10. Christopher T. Genetic Failures, Mental Disorders, and the Reincarnation Alternative. Ment Health Fam Med. 2019; 15:842-53.

11. Christopher T. A Hole in Science: An Opening for an Alternative Understanding of Life. Expanded 3rd ed. Baltimore: Wise Media Group, USA; 2017. See discussion in the final chapter.

12. Barrett JL. Born Believers - The Science of Children's Religious Belief. New York, NY: Free Press, USA; 2012.

13. Barrett JL. Born Believers - The Science of Children's Religious Belief. New York, NY: Free Press, USA; 2012. 3 p.

14. Barrett JL. Born Believers - The Science of Children's Religious Belief. New York, NY: Free Press, USA; 2012. 120 p.

15. Barrett JL. Born Believers - The Science of Children's Religious Belief. New York, NY: Free Press, USA; 2012. 2 p.

16. Bering J. One Last Goodbye: The Strange Case of Terminal Lucidity. Scientific American Blog entry November 2014. Available from: https://blogs.scientificamerican.com/bering-in-mind/one-last-goodbye-thestrange-case-of-terminal-lucidity/ [Accessed on December 9, 2019].

17. Kapleau P. Three Pillars of Zen: Teaching, Practice, and Enlightenment. Garden City, NY: Anchor Books, USA; $1980.215-9$ p.

18. Iwasaki/Kapleau. Yaeko Iwasaki's Enlightenment Letters to Harada-Roshi and his Comments. In addition to Three Pillars of Zen it also found available at https://sites.google.com/site/esabsnichtenglisch/yaeko-iwasaki-senlightenment-letters-to-harada-roshi-and-his-comments . [Accessed on November 3, 2019].

19. MacFarquhar L. Last Call. The New Yorker, June 24, 2013 . Available from: www.newyorker.com/magazine/2013/06/24/last-call-3 [Accessed on December 9, 2019].

20. Lusseyran J. And There Was Light. Novato, CA: New World Library, USA; 2014.

21. Christopher T. Science's Big Problem, Reincarnation's Big Potential, and Buddhists’ Profound Embarrassment. 2017a. Available from: http://www.mdpi.com/2077-1444/8/8/155 [accessed on May 30, 2019].

22. Nisargadatta S. I AM THAT. Durham, NC: Acorn Press, UK; 1973. (paperback printing 1999). 278 p.

23. Solomon A. Far From the Tree: Parents, Children, and the Search for Identity. New York, NY: Scribner, USA; $2012.198 \mathrm{p}$.

24. Luhrmann TM. Beyond the Brain. The Wilson Quarterly, Summer. 2012:28-34. 